$100 \mathrm{ml}$. conical flask containing $25 \mathrm{ml}$. of culture solution consisting of Linsmaier and Skoog's ${ }^{5}$ nutrient medium without the optional constituents and with the indoleacetic acid concentration at $8 \mathrm{mg} / \mathrm{l}$. and kinetin at $2 \cdot 56 \mathrm{mg} / \mathrm{l}$. The flasks were fixed horizontally onto an illuminated vertical wheel which was rotated at 8 r.p.m. Within 3-4 weeks each tip developed into a mass of callus bearing several terminal leaf initials (Fig. 1). After a further 3-4 weeks, protrusions of the callus developed below these initials, each bearing several small green leaves. The protrusions became detached and "budded" profusely into a ball of callus units (Fig. 2), many of which also became detached and continued to proliferate. This process was accelerated if the cultures were grown on a horizontal shaker operating at approximately 80 cycles/ $\min$.

The proliferation into callus units continued if portions of the culture were transferred to new flasks and the shaking was maintained. If, however, the callus units

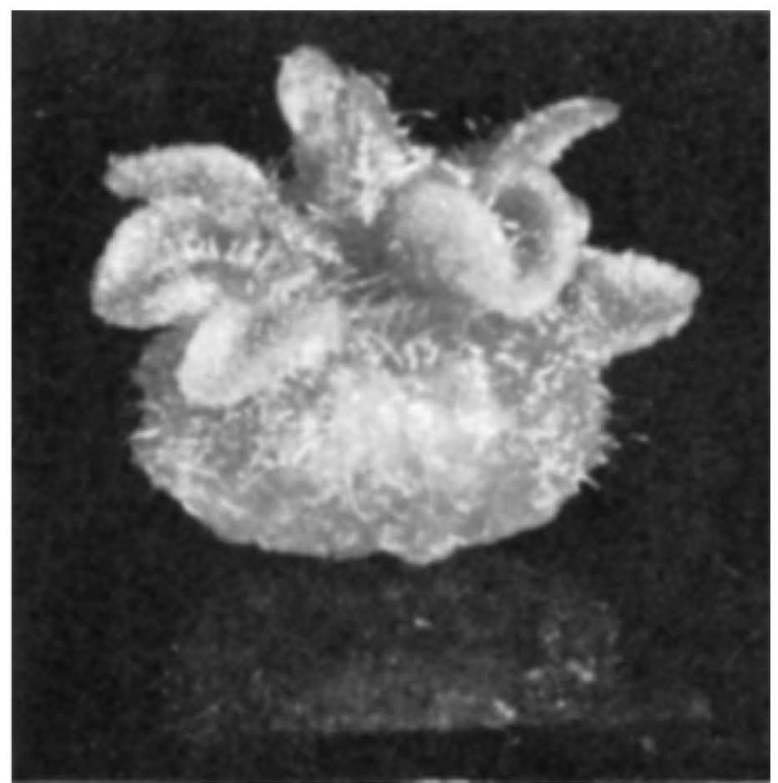

Fig. 1. 3-4 week old culture showing callus mass and terminal eaf initials. $(\times 15$.

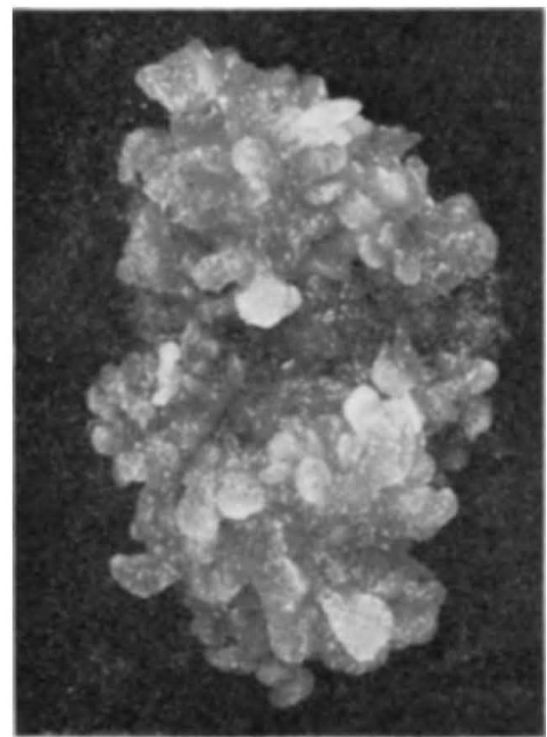

Fig. 2. 5-8 week old culture showing "ball" of proliferating eallus protrusions. $(\times 3$.

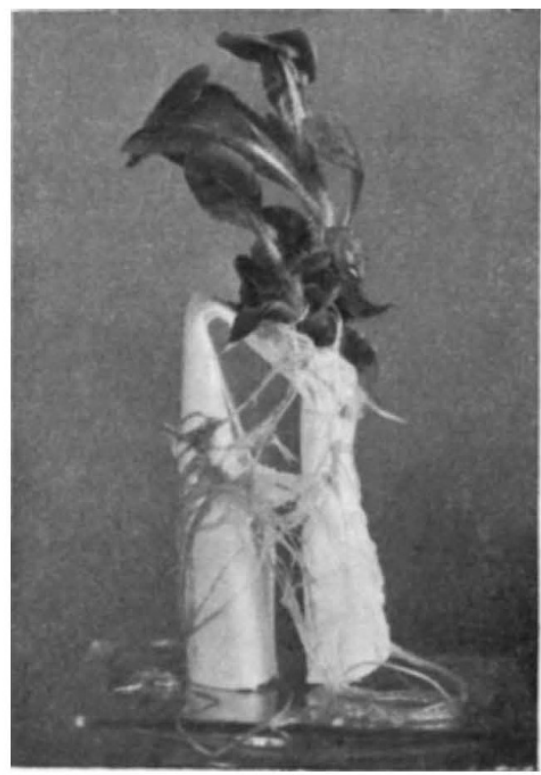

Fig. 3. Young $N$. rustica plant produced after transfer to still culture. $(\times 2 / 3$.

were removed and placed on filter paper bridges in still culture $^{6}$, each developed roots and shoots and grew into a normal plant (Fig. 3).

This method of culture enabled very large numbers of clonal plants to be raised from one apical tip. It seems to be the first occasion on which propagation of a dicotyledonous plant from a meristem by this particular means has been demonstrated, although somewhat similar cultures have been made from single cell and callus tissue of carrot and other plants ${ }^{7-10}$. It has also been shown ${ }^{11}$ that carnation meristems can be induced to form multiple apices in culture from which numerous explants can be grown.

The possible application of the shake culture method for the multiplication of other dicotyledonous plants is being investigated.

We thank Dr M. E. Marston for advice and Miss S. Whittingham-Jones for technical assistance.

D. G. A. WALKEX

J. M. G. WoorfitT

National Vegetable Research Station, Wellesbourne, Warwick.

Received November 13, 1968.

${ }^{1}$ Morel, G. M., Amer. Orchid Soc. Bull., 29, 495 (1960).

${ }^{2}$ Wimber, D. E., Amer. Orchid Soc. Bull., 32, 105 (1963).

${ }^{3}$ Wimber, D. E., Cymbidium Soc. News, 20, 7 (1965).

- Stone, O. M., Ann. Appl. Biol., 52, 199 (1963).

${ }^{5}$ Linsmaier, E. M., and Skoog, F., Physiol. Plant., 18, 100 (1965).

'Walkey, D. G. A., J. Hort. Sci., 43, 283 (1968).

'Steward, F. C., Mapes, M. O., and Mears, K., Amer. J. Bot., 45, 705 (1958)

${ }^{8}$ Wetherell, D. F., and Halperin, W., Nature, 200, 1336 (1963).

"Vasil, I. K., and Hildebrandt, A. C., Science, 150, 889 (1965).

1 "Vasil, I. K., and Hildebrandt, A. C., Amer. J. Bot., 53, 860 (1966).

"Hackett, W. P., and Anderson, J. M., Proc. Amer. Soc. Hort. Sci., 90, 365 (1967).

\section{Rubella Haemagglutinin prepared in BS-C-I Cells}

STEWART et al. ${ }^{1}$ described procedures for the preparation of rubella virus haemagglutinin in monolayers of BHK21 cells. Others expanded these studies to include extraction of haemagglutinin with high $p \mathrm{H}$ buffers from BHK21 suspension cultures infected with rubella virus ${ }^{2}$. Produc- 
tion of rubella virus haemagglutinin in an established line of African green monkey kidney cells (VERO) was recently reported ${ }^{3}$. We describe the production of haemagglutinin in the BS-C-1 line of African green monkey cells by two different strains of rubella virus and subsequent establishment of a chronically infected culture which continues to shed virus and haemagglutinin after serial passage.

BS-C-1 cells in the forty-ninth passage and rubella virus, strain Putnam, were obtained from the Division of Biologies Standards, US National Institutes of Health, and rubella virus, strain Baylor, was received from Dr W. Rawls, Baylor University. Virus titrations wero carried out by the ECHO 11 interference test ${ }^{4}$ and are expressed as tissue culture interference dose-50 per cent/ $0.1 \mathrm{ml}$. Titres and passage histories of virus pools used were as follows: Putnam, 105.5, RK13/12, MAI04/1, BHK21/2; and Baylor, 10.7, BHK21/6. Haemagglutination and haemagglutination inhibition tests were carried out with erythrocytes from 1 day old chicks by methods previously described ${ }^{5}$.

BS-C-1 monolayers were prepared in 4 ounce glass prescription bottles and inoculated with rubella virus at a multiplicity of 5. After incubation for $2 \mathrm{~h}$ at $36^{\circ} \mathrm{C}$, the cells were rinsed three times with saline and fed a measured volume $(15 \mathrm{ml}$.) of medium 199 containing 2 per cent kaolin-treated foetal bovine serum. Infected and uninoculated control cultures were incubated at $36^{\circ} \mathrm{C}$ and observed daily for cytopathic effects (CPE). Maintenance medium was replaced daily and harvests tested for the presence of haemagglutinins without prior treatment.

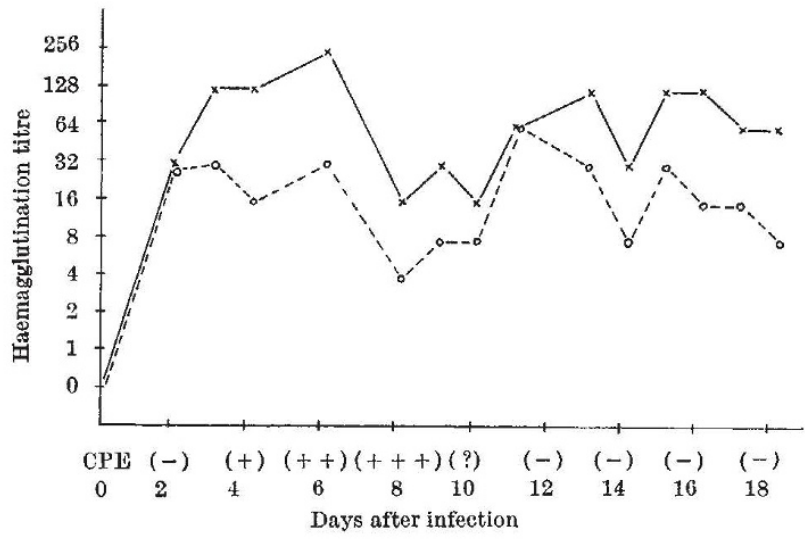

Fig. 1. Production of haemagglutinins in BS-C-1 cells by the Putnam $(x)$ and Baylor $(O)$ strains of rubella virus.

Results from a typical experiment are summarized in Fig. 1. Hacmagglutination antigen was detected 2 days after infection and reached maximum titre within 3 days. Between 6 and 8 days the hacmagglutination titre dropped 8-16-fold in eultures infected with both Putnam and Baylor and then gradually increased to previous levels. The sharp drop in titre coincided with extensive cell destruction. Haemagglutinin was present in all harvests throughout 18 days. Harvests from Putnam infected cells usually contained 4 -fold higher titres of haemagglutinin than cells infected with Baylor. CPE was first observed in cultures on the fourth day after infection and progressed to involve most of the cells by the eighth day. Cells appeared granular, pyknotic and loosely attached giving a "peppered" appearance to the culture. CPE did not progress completely to destroy the cells and by 10-12 days it became increasingly difficult to distinguish infected from uninoculated control cultures. By 18 days a light monolayer had once again formed which was indistinguishable from the control culture.
It was of interest to determine whether BS-C-1 cells that had been infected by rubella virus and showed extensive CPE and then sheeted out again could be passaged. We therefore chose a culture infected 18 days with Putnam and dispersed the cells with 0.25 per cent trypsin and subcultured at a 2:1 ratio in medium 199-20 per cent foetal bovine serum. Cultures were split 2:1 every 5-7 days thereafter. When cultures became confluont they wore rinsed twice with saline and refed medium 199-20 per cent kaolin-treated foetal bovine serum. The following day the medium was harvested and titrated for virus and haemagglutinin and the cells subcultured. Results after five serial passages are presented in Table 1. The cells are chronically infected as shown by the continued shedding of low levels of virus $\left(0 \cdot 7-2 \cdot 3 \quad \log _{10}\right)$ and moderate amounts of haemagglutinin throughout each of five passages.

\begin{tabular}{|c|c|c|c|}
\hline Passage No. & $\begin{array}{l}\text { Interval after } \\
\text { infection (days) }\end{array}$ & $\begin{array}{l}\text { Infectivity titre* } \\
\left(T C I D_{50} / 0.1 \mathrm{ml} .\right)\end{array}$ & $\begin{array}{l}\text { Haemagglutination } \\
\text { titre }^{*}\end{array}$ \\
\hline $\begin{array}{l}1 \\
2 \\
3 \\
4 \\
5\end{array}$ & $\begin{array}{l}28 \\
33 \\
40 \\
45 \\
50\end{array}$ & $\begin{array}{l}1 \cdot 7 \\
0 \cdot 7 \\
1 \cdot 5 \\
1 \cdot 7 \\
2 \cdot 3\end{array}$ & $\begin{array}{r}16 \\
8 \\
64 \\
16 \\
32\end{array}$ \\
\hline
\end{tabular}

* Titre of overlay fluid on day of split.

Table 2. RUBELLA HARMAGGLUTINATION TNHIBTTTON TITRES IN RANDOM HUMAN SERA TESTED WITH THREE DIFFERENT H.AEMAGGLTINATION ANTYGEN PREPARATIONS

\begin{tabular}{cccc} 
Sera & \multicolumn{3}{c}{ Haemagglutination antigen } \\
identification & $\begin{array}{c}\text { Putnam prepared } \\
\text { in BS-C-1 }\end{array}$ & $\begin{array}{c}\text { Baylor prepared } \\
\text { in BS-C-1 }\end{array}$ & $\begin{array}{c}\text { Commereial pre- } \\
\text { pared in BHK21 }\end{array}$ \\
6 & $<8$ & $<8$ & $<8$ \\
65 & $<8$ & $<8$ & $<8$ \\
66 & $<8$ & $<8$ & $<8$ \\
73 & $<8$ & 32 & 32 \\
25 & 16 & 64 & 64 \\
163 & 64 & 32 & 128 \\
60 & 64 & 258 & 128 \\
59 & 128 & 256 & 512 \\
68 & 128 & 1,024 & 512 \\
76 & 256 & 1,024 & 2,048 \\
160 & 256 & 4,096 & 4,096
\end{tabular}

Rubella virus hacmagglutinins produced in BS-C-l by the Putnam and Baylor strains and a commercial antigen prepared in BHK21 cells were used to measure haemagglutination inhibition antibody in thirteen human sera (Table 2). A titre of less than 8 was obtained in four sera with each of the three antigens. Rubclla virus haemagglutinins propared in BS-C-1, similar to haemagglutination antigen prepared in VERO cells, were as sonsitive in measuring haemagglutination inhibition antibody as antigen prepared in BHK21 cells.

These results further cstablish that production of rubella haemagglutination antigen is not unique to a particular virus-host cell system but rather a common occurrence requiring only infection of cells at a high input multiplicity and initial replication of virus to rolatively high titres. Continued proliferation at high titre does not seem necessary because haemagglutination antigen was shed from chronically infected cells producing relatively small quantities of virus. It has been reported ${ }^{3,7}$ that low levels of infectious rubella virus were obtained from chronically infected human foetai tissue and LLC$\mathrm{MK}_{2}$ cells, but no data were available on haemagglutination production.

This work was supported by a contract from the Vaccine Development Board, National Institute of Allergy and Infectious Diseases, US National Institutes of Health.

ROBERT R. RAFAJKo

DOROTHY ZIR NEDDEN

Medical Research Consultants,

12601 Twinbrook Parkway,

Rockville, Maryland.

Received Oetober 7, 1968 
${ }^{1}$ Stewart, G. L., Parkman, P. D., Hopps, H. E., Douglas, R. D., Hamilton, J. P., and Meyer, jun., H. M., N. Engl. J. Med., 276, 554 (1967).

${ }^{2}$ Halonen, P. E., Ryan, J. M., and Stewart, J. A., Proc. Soc. Exp. Biol. and Med., 125, 162 (1967).

s Rafajko, R. R., and zur Nedden, D. L., Appl. Microbiol., 16, 803 (1968).

- Parkman, P. D., Buescher, E. L., and Artenstein, M. S., Proc. Soc. Exp. Biol. and Med.,111, 225 (1962)

${ }^{5}$ Rafajko, R. R., Polakavetz, S., Handelman, B., and zux Nedden, D. L., Appl. Microbiol..16. 423 (1968).

${ }^{6}$ Massab, H. F., and Veronelli, J. A., J. Sact., 91, 436 (1966).

' Plotkin, S. A., Amer. J. Hed. Sci., 253, 132/356 (1967).

\section{Effect of Preliminary Irradiation of Mice on Radioresistance of Immunologically Competent Spleen Cells}

RESISTANCE to radiation is increased in animals repeatedly exposed to ionizing radiation ${ }^{1-6}$. We know of no quantitative studies of radiosensitivity of haematopoietic or immunocompetent cell populations from previously irradiated animals.

Our aim has been to compare the radioresistance of immunologically competent cells from intact and previously irradiated animals by counting the affected cells. The plaque technique ${ }^{7}$ has made possible the determination of a number of single antibody-forming cells ${ }^{7}$.

The animals were $(\mathrm{C5} 7 \mathrm{~B} \times \mathrm{CBA}) \mathrm{F}_{1}$ female mice which weighed 18-20 g, and were 3-4 weeks old. 'The principle of the method used to obtain antibody-forming cells has been described before ${ }^{8,9}$. Spleens of intact and previously irradiated $(500$ r.) donors were removed and suspensions of spleen cells were prepared in IC 199 medium 1 (ref. 10) 7-21 days after irradiation. Samples of the cell suspension were irradiated in vitro with doses varying from 0 to $1,000 \mathrm{r}$. The cells were then washed two or three times with TC 199 medium and, after washing, sheep red blood cells were added to each sample. The treated cells were injected into lethally irradiated $(850 \mathrm{r}$.$) syngeneic re-$ cipients. Each recipient received $0.5 \mathrm{ml}$. of mixture, consisting of $25 \times 10^{6}$ spleen cells and $2 \times 10^{8}$ sheep red blood cells. Because preliminary experiments had shown that maximal accumulation of cells producing antibody is reached in the spleen of the recipients on the sixth day after the transfer of the cells the recipients were killed 6 days after injection. Their spleens were removed and suspensions of spleen cells were prepared. Antibody-forming cells were counted by the Jerne plaque technique ${ }^{7}$. Mice and suspensions of cells were irradiated with ${ }^{60} \mathrm{Co}$ $\mathrm{X}$-rays in an EGO-2 apparatus, at a dose rate of $641-587 \mathrm{r}$. $\min$

The injection of spleen cells stimulated by antigen from normal mice into lethally irradiated recipients resulted in the accumulation in their spleens of $\sim 2,500 \times 10^{-8}$ antibody-forming cells. Use of the same quantity of transplanted cells from previously irradiated donors (500 r.) led to a significantly smaller accumulation of cells producing antibody. There were about $150 \times 10^{-8}$ cells if the donors were irradiated 7 days before the spleens were removed, and $\sim 170 \times 10^{-8}$ if spleens were removed 21 days after irradiation.

Cell suspensions from intact and previously irradiated donors were radiated in vitro. The results (dose response) for three groups of the cell populations are summarized in Fig. 1. In each case inactivation of antibody-forming cells was calculated as a percentage with respect to the value obtained in each experiment with a non-irradiated in vitro cell suspension. Curve 1 characterizes the dose response of spleen cells from intact donors. Using the exponential part of this curve, the $D_{37}$ was calculated to be $125 \mathrm{r}$. and the extrapolation number $(n)$ is $1.0\left(L D_{50}=\right.$ $95 \mathrm{r}$.). The dose response curve of mouse spleen cells irradiated 7 days before the beginning of radioresistance studies was characterized as $D_{37}=325 \mathrm{r}$. and $n=1 \cdot 0$ $\left(L D_{50}=235 \mathrm{r}.\right)$. The greatest difference in accumulation of antibody-forming cells, in comparison with the normal cell suspension, occurred when the spleen cells were isolated from the donors 21 days after the preliminary irradiation. The inactivation curve of antibody-producing cells then gave $D_{37}=180 \mathrm{r}$. and $n=23\left(L D_{50}=680 \mathrm{r}\right.$. $)$. These results indicate that the population of immunocompetent spleen cells in the body of previously irradiated mice is significantly more radioresistant than that in intact animals.

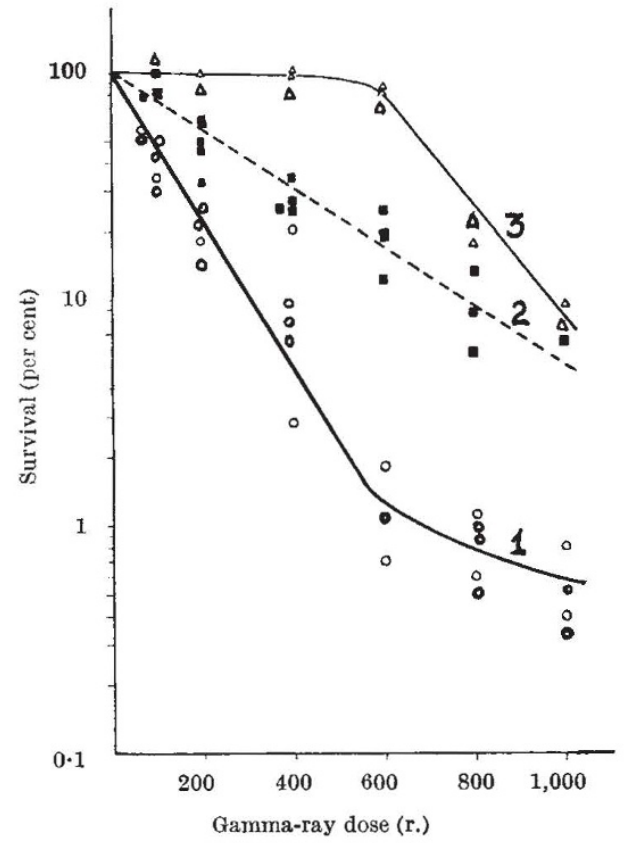

Fig. 1. Effect of irradiation of spleen cell suspensions on the accumulation of antibody-producing cells after antigenic stimulation. $\bigcirc$, Inactivation curve for spleen cells from intact mice; $\boldsymbol{\square}$, inactivation curve for spleen cells from mice irradiated (500 r.) 7 days and, $\triangle, 21$ days before iradiation in vitro. Every point represents data obtained from at curve $3, D_{3}=180 \mathrm{r}, n=23$.

One possible explanation is that there are a few radioresistant stem cells or immunocompetent cell precursors in the body of a normal animal. Preliminary irradiation damages a radiosensitive cell population and could be a selecting factor for the pre-existing cell population of radioresistant cells, so that the ratio of the two cell populations changes in favour of radioresistant cells. Theoretical analysis shows that curve 1 agrees most closely with two possibilities: ( 1 ) there is 1 per cent of radioresistant cells which are six times more radioresistant than the remaining 99 per cent of cells, and (2) there is 5 per cent of radioresistant cells, which are four times more radioresistant than the remaining 95 per cent.

This may be correct ${ }^{11}$, but there is another possible explanation for our results in another way. The radioresistance of immunocompetent cells which has been demonstrated in previously irradiated mice is probably only a relative phenomenon. The spleen cell population is very heterogenic. The most typical form of cell inactivation occurs when cells are able to divide one, two or more times before death ${ }^{12,13}$. The generation time of such cells is longer than usual. If the number of cells capable of limited division after exposure to ionizing irradiation is the same in both normal and previously irradiated populations, it is simple to calculate that the percentage of such cells in an irradiated normal spleen cell population 